\title{
Whistleblowing System, Competence, Morality, and Internal Control System Against Fraud Prevention on Village Financial Management in Denpasar
}

\author{
I Ketut Sujana ${ }^{1}$ \\ Fakultas Ekonomi dan Bisnis \\ Universitas Udayana, Indonesia
}

\author{
I Made Sadha Suardikha ${ }^{2}$ \\ Fakultas Ekonomi dan Bisnis \\ Universitas Udayana, Indonesia
}

\section{Putu Santi Putri Laksmi ${ }^{1}$ \\ Fakultas Ekonomi dan Bisnis \\ Universitas Udayana, Indonesia}

\begin{abstract}
Surel: ketutsujana_fe@yahoo.com
ABSTRACT

This study aims to test empirically the effect of the whistleblowing system, human resource competence, morality and internal control systems on fraud prevention in village financial management. The data source used is primary data from the results of distributing questionnaires to village officials who are involved as managers of village fund allocations as many as 97 respondents. The sampling technique was the total method or census, namely 27 Dinas Villages in Denpasar City and data analysis used multiple linear regression analysis. The results of this study indicate that the whistleblowing system has no effect on fraud prevention in village financial management. Meanwhile, human resource competence, morality, and internal control systems have a positive effect on fraud prevention in village financial management.
\end{abstract}

Keywords: Whistleblowing System; Human Resource Competence; Morality; Internal Control System; Fraud.

\section{Whistleblowing System, Kompetensi, Moralitas, dan Sistem Pengendalian Internal Dalam Mencegah Kecurangan pada Manajemen Dana Desa di Denpasar}

\begin{abstract}
ABSTRAK
Penelitian ini bertujuan untuk menguji secara empiris pengaruh whistleblowing system, kompetensi sumber daya manusia, moralitas dan sistem pengendalian internal terhadap pencegahan kecurangan dalam pengelolaan keuangan desa. Sumber data yang digunakan adalah data primer dari hasil penyebaran kuesioner kepada aparat desa yang terlibat sebagai pengelola alokasi dana desa sebanyak 97 responden. Teknik pengambilan sampel dengan metode total atau sensus yaitu 27 Dinas Desa di Kota Denpasar dan analisis datanya menggunakan analisis regresi linier berganda. Hasil penelitian ini menunjukkan bahwa whistleblowing system tidak berpengaruh terhadap pencegahan kecurangan dalam pengelolaan keuangan desa. Sedangkan kompetensi sumber daya manusia, moralitas, dan sistem pengendalian intern berpengaruh positif terhadap pencegahan kecurangan dalam pengelolaan keuangan desa.

Kata Kunci: Whistleblowing System; Kompetensi Sumber Daya Manusia; Moralitas; Sistem Pengendalian Internal; Kecurangan.
\end{abstract}

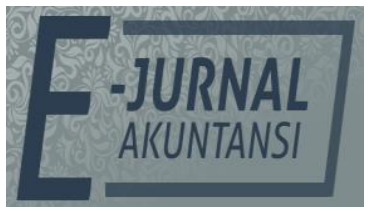

e-ISSN 2302-8556

Vol. 30 No. 11

Denpasar, Nopember 2020

Hal. 2780-2794

DOI:

10.24843/EJA.2020.v30.i11.p06

\section{PENGUTIPAN:}

Sujana, I K., Suardikha, I M. S., \& Laksmi, P.S.P. (2020). Whistleblowing System, Competence, Morality, and Internal Control System Against Fraud Prevention on Village Financial Management in Denpasar. EJurnal Akuntansi, 30(11), 2780-2794

RIWAYAT ARTIKEL: Artikel Masuk: 11 November 2020 Artikel Diterima: 28 November 2020

Artikel dapat diakses : https://ojs.unud.ac.id/index.php/Akuntansi/index 


\section{INTRODUCTION}

The Indonesian government, through President Joko Widodo (Jokowi) 's Nawacita program, is committed to developing Indonesia by increasing development in villages. Law of the Republic of Indonesia Number 6 of 2014 concerning villages provides a mandate to the Government to allocate village funds. The provision of large village fund allocations has consequences for fraud committed by certain parties, in particular those who have been trusted by the community. Fraud is an act that is carried out by a person or group illegally, intentionally or unintentionally, to gain profit by obtaining money, assets and so on so that it can harm other people or certain parties (Aini et al., 2017).

The phenomenon of village financial management cases has occurred in Indonesia. The results of monitoring conducted by Indonesia Corruption Watch (ICW) stated that from 2015 to 2017 cases of corruption in the village had increased. There were 127 cases of misuse of the village budget that occurred. Village heads has misuse village budgets in some way (Indonesian Corruption Watch, 2018). Based on the results of a study conducted by the Corruption Eradication Commission (KPK), the KPK identified four aspects that could trigger corruption in village financial management, namely in regulatory and institutional aspects, governance aspects, supervision aspects and human resources aspects.

One of the regencies/cities in Bali, namely the Denpasar City Government, is committed to efforts to prevent fraud. However, there is a phenomenon of fraud in the Denpasar City Service Village. Based on the findings of the Denpasar Police Corruption Task Force Unit, there are allegations of misuse of village finances in Pemecutan Kaja Village, North Denpasar District by the Village Head from January 2017 to January 2018. Village financial losses in this case reached IDR 120 million. Based on the report on the results of the second semester supervision carried out by the Bali Province Financial and Development Supervisory Agency (BPKP), there are several problems in the management of village funds in Denpasar City (Suarna, 2020). As for the problems that occur, namely in the administration of village financial management there are still errors in the implementation of the Siskeudes application, there are budgeting errors in the APBDes, BUMDesa has not set the articles of association and bylaws and has not recorded assets for the work that has been completed (Wijaya, 2018).

In line with reports of cases of misappropriation of village funds that have occurred, community participation is needed in monitoring and evaluating the use of village finances. In addition, preventive measures are also needed to minimize the occurrence of fraud. Fraud prevention is an effort or action taken to suppress or prevent the factors that cause fraud. So that there is a need for fraud prevention efforts that can suppress fraudulent acts such as the existence of an effective whistleblowing system (Latifah, 2011), prioritizing and instilling thoughts about morality (Novikasari et al., 2016), apparatus competence and a good internal control system capable of preventing the occurrence of fraud (Atmadja \& Saputra, 2017). Based on this, the purpose of this study is to determine how much influence the whistleblowing system, competence of 
human resources, morality and internal control systems have on fraud prevention in village financial management.

Fraud can be prevented with a whistleblowing system. The whistleblowing system is a mechanism for submitting complaints about suspected criminal acts of corruption that have occurred or will occur involving employees and other people related to suspected criminal acts of corruption committed within the organization where they work (Larasati et al., 2017). An effective whistleblowing system will encourage public and employee participation to be more courageous in taking action to prevent fraud and corruption by reporting it to parties who can handle it (Latifah, 2011). With the whistleblowing system, the use of village funds can be better monitored and fraud in village financial management can be prevented.

Research on the effect of the whistleblowing system on fraud prevention was conducted by Agusyani et al. (2016) stated that partially the whistleblowing system has a significant effect on fraud prevention. This statement is supported by research conducted by Wardana et al. (2017) which states that the whistleblowing system has a positive and significant effect on fraud prevention. However, the results of this study are not in line with research conducted by Wahyuni \& Nova (2019) which found that the whistleblowing system is not the only way that can be used to prevent fraud, there are also other factors that influence it.

Putri et al. (2017) said that the Village Government in terms of managing village finances is required to carry out tasks accountably and transparently so that funds misuse of funds will not occur. Therefore, the competence of quality human resources is needed to carry out duties and obligations in village financial management. Human resource competence is the ability that a person or individual has in dealing with situations or circumstances in carrying out their job responsibilities. Based on Law Number 13 of 2013 concerning Manpower, a person's competence factor is related to individual ability which includes aspects of knowledge, skills and work attitudes. Wardani \& Andriyani (2017) explain that in good regional financial management, village officials must have quality human resources, supported by educational and training backgrounds and have experience in the financial sector. Lack of competence in understanding and applying accounting logic will have an influence on the errors of the financial statements made and the report's inconsistencies with the standards set by the Government, so that the information received by users will be incorrect and will affect the decisions to be taken next (Ferina et al., 2016).

Research conducted by Atmadja \& Saputra (2017) states that apparatus competence affects the prevention of fraud in village financial management. This statement is supported by research conducted by Mahayani (2017) which states that human resource competence has a positive effect on the accountability of village fund management. However, the results of this study are not in line with the research conducted by Indriani et al. (2016) which states that competence does not affect the tendency for fraud to occur.

Morality can affect ethics or actions that are done by a person. Individual morality will relate to a person's tendency to commit accounting fraud (Ariyanto et al., 2020; Dennyningrat \& Suputra, 2018). To prevent fraud, efforts can be 
made by prioritizing and instilling thoughts about morality (Novikasari et al., 2016). Morality is a person's attitude or behavior (Junia, 2016). Someone who has low moral reasoning will have a different perspective from someone who has high morals in facing ethical dilemmas (Liyanarachchi \& Newdick, 2009). According to Rahimah et al. (2018) individuals who have a high moral level will be able to prevent cheating because individuals who have high morals will obey the rules according to universal ethical principles, and vice versa, individuals who have low moral tend to make decisions based on what he wants and does not comply with the rules and obligations that should be fulfilled. (Manossoh, 2016) explains that officials who have good behavior will make financial management run well, and vice versa.

The research on the effect of morality on fraud prevention, namely research conducted by Wardana et al. (2017) states that partially apparatus morality affects fraud prevention. This statement is supported by research conducted by Setiawan (2018) which states that individual morality affects accounting fraud. However, the results of this study are not in line with research conducted by Dewi et al. (2017) which states that morality does not have a significant effect on fraud prevention.

Fraud in village financial management can be minimized and prevented by paying attention to the internal control system. The internal control system is a process that is carried out to provide confidence in the achievement of the reliability of financial reports and compliance with law. The Committee of Sponsoring Organizations (2013) explains that there are five indicators contained in the internal control system, namely control environment, risk assessment, control activities, information and communication as well as internal control monitoring. A good internal control system is able to prevent fraud in village financial management, especially that village finances are supervised by the Central, Provincial, Regency or City Government and independent financial institutions (Atmadja \& Saputra, 2017). The stronger the internal control system found in the Village Government, the fraud and errors that may occur in village financial management can be minimized and prevented and if internal control is weak, the chances of fraud that will occur are even greater.

Fraud is fraud which means something that is deviant and acts against the law that are done intentionally to deceive or give a wrong picture or interpretation to certain parties, both from inside and outside the organization. Fraudulent actions that are carried out can cause many losses, both material and non-material, such as the destruction of the organization's reputation, losses to state finances, damage to employee morality and other negative impacts (Indriani et al., 2016).

There are two types of accounting fraud according to the IAPI (2013), the first is misstatement arising from fraud in financial reporting, namely misstatement or deliberate omission of amounts or disclosures in financial statements that aim to deceive users of financial statements and the second is wrong. representations arising from improper treatment of assets (often referred to as misuse or embezzlement).

Wahyuni \& Nova (2019) revealed that the Financial and Development Supervisory Agency defines fraud prevention as an effort to suppress the factors 
that cause fraud by minimizing the opportunity for opportunities to commit fraud, reducing pressure on employees to be able to meet their needs and developing an organizational code of ethics. and eliminate various forms of justification for committing fraud.

The allocation of village funds is part of village financial management which is described in more detail through the APBDes. Village financial management is carried out by the Village Government. The Village Government is a person who has the authority and responsibility in carrying out implementation in the Village Government, namely the Village Head who is assisted by the Village Secretary, Treasurer and Section Head. Village financial management must be based on the principles of transparency, accountability, participation and be carried out in an orderly and disciplined budget as stated in the Minister of Home Affairs Regulation Number 113 of 2014 concerning Village Financial Management.

The whistleblowing system according to Wahyuni \& Nova (2019) is a forum for a whistleblower to complain about fraud or violations committed by internal parties of the organization. With the whistleblowing system, it is hoped that it can minimize and prevent fraud in village financial management. So that the use of village fund allocations provided by the Government can be used in accordance with the interests of the community and not for personal or certain group interests. Research by Latifah (2011) states that the whistleblowing system has a significant effect on fraud prevention. This research is supported by research conducted by Widiyarta et al. (2017) which states that whistleblowing has a positive and significant effect on fraud prevention in the management of village funds. Based on the review above, the hypothesis in this study is as follows.

$\mathrm{H}_{1}$ : The whistleblowing system has a positive effect on fraud prevention in village financial management.

Sugiarti \& Yudianto (2017) explain that human resource competence includes the capacity, namely the ability of an individual, an organization (institutional) or a system to carry out its functions or authority to achieve its goals effectively and efficiently. Capacity must be seen as the ability to achieve performance, to produce outputs and outcomes. In village financial management, the village government must have competent quality human resources supported by an educational background, experience, attending training, understanding village accounting and finance and understanding regulations and procedures regarding village financial management along with the purpose of these funds being provided by the Government. This is necessary so that there are no mistakes in the management of village finances and inconsistencies in reports made based on financial management standards that have been set by the Government.

Research conducted by Huslina et al. (2015) states that apparatus competence has a positive effect on the effectiveness of the fraud prevention system. This research is supported by research conducted by Widiyarta et al. (2017) which states that the competence of village governments has a positive and significant effect on fraud prevention in the management of village funds. Based on the review above, the hypothesis in this study is as follows. 
$\mathrm{H}_{2}$ : Human resource competence has a positive effect on fraud prevention in village financial management.

Morality or what is usually referred to as morality is a teaching about the good and bad deeds and attitudes of a person or individual, whereas morality is a consideration of a person's morals (Junia, 2016). Morality is very much needed to prevent fraud or fraud that is committed, especially in village financial management, this is because if someone has good morality, the use and management of village funds will run according to prioritized needs. This is in line with research conducted by Wardana et al. (2017) which states that partially apparatus morality affects fraud prevention and Rahimah et al. (2018) which proves that morality affects fraud prevention in the allocation of village funds. Based on the review above, the hypothesis in this study is as follows.

$\mathrm{H}_{3}$ : Morality has a positive effect on fraud prevention in village financial management.

The internal control system is a way to supervise, direct and measure the resources of an institution or organization and has an important role in preventing and detecting any acts of fraud or fraud. Internal control must have clear policies and procedures that aim to guarantee and provide financial information reports in accordance with established procedures (Wardani \& Andriyani, 2017). With an internal control system, the village financial management process can be directed, monitored and can be detected if there is fraud so that the report can be accounted for.

This is in line with Soleman (2013) research which states that internal control has a positive effect on fraud prevention and research conducted by Atmadja \& Saputra (2017) which states that the internal control system affects fraud prevention in village financial management. Based on the review above, the hypothesis in this study is as follows.

$\mathrm{H}_{4}$ : The internal control system has a positive effect on fraud prevention in village financial management.

\section{METHODOLOGY}

The data used in this study are primary data. The population of this study is the Village Government involved in village financial management starting from the planning, implementation, administration, reporting and accountability stages, consisting of the Village Head, Village Secretary, Village Treasurer and Village Consultative Body (BPD) in 27 (twenty seven) Village Service in Denpasar City. The sampling technique used was non-probability sampling in which all members of the population were sampled, namely 27 Dinas Villages in Denpasar City with 108 respondents, and data that could be used were 97 respondents. The data analysis technique used is multiple linear analysis.

$Y=\alpha+\beta_{1} X_{1}+\beta_{2} X_{2}+\beta_{3} X_{3}+\beta_{4} X_{4+} \varepsilon$

\section{RESULT AND DISCUSSION}

The results of descriptive statistics to describe the data related to the analyzed variables are shown in Table 1. 
Table 1. Descriptive Statistics Results

\begin{tabular}{lcrrrr}
\hline \multicolumn{1}{c}{ Variable } & $\mathrm{N}$ & Minimum & Maximum & Mean & $\begin{array}{c}\text { Std. } \\
\text { Deviation }\end{array}$ \\
\hline Whistleblowing System $\left(\mathrm{X}_{1}\right)$ & 97 & 2.420 & 4.000 & 3.130 & 0.361 \\
$\begin{array}{l}\text { Human Resource Competence } \\
\left(\mathrm{X}_{2}\right)\end{array}$ & 97 & 2.600 & 4.000 & 3.310 & 0.350 \\
Morality $\left(\mathrm{X}_{3}\right)$ & & & & & \\
Internal Control System $\left(\mathrm{X}_{4}\right)$ & 97 & 2.400 & 4.000 & 3.190 & 0.376 \\
Fraud $(\mathrm{Y})$ & 97 & 2.680 & 4.000 & 3.290 & 0.388 \\
\hline Soure: & 2.000 & 4.000 & 3.120 & 0.364 \\
\hline
\end{tabular}

Source: Processed Data, 2020

The minimum value on the whistleblowing system variable is 2.42 , this is based on the data showing that respondents do not like to use anonymous names reporting if there is fraud. The maximum value is 4 , the highest average respondent's answer value is close to 4 indicating that they are motivated to report, to attend training and education in the whistleblowing system program.

The minimum value on the human resource competency variable is 2.60 . From the respondents' answers, the average value who answered the statement was close to 2.6 which indicates that the respondent has not been able to solve problems that occur in their work and understand and are able to compile good village financial reports. The maximum value of 4 , which answers statements with an average value close to the maximum, means that the respondent has understood the rules, can complete his work in accordance with existing procedures and rejects all forms of bribery. The standard deviation value of 0.350 is smaller than the average value, meaning that the deviation of the respondent's answer to the human resource competency variable is very small.

The minimum value on the morality variable is 2.40 , which the respondents tend to disagree with in the case of ethical dilemmas with bad morality. The maximum value is 4 , from the average value of the respondent's statement approaching the maximum value, it means that the respondent will carry out tasks based on good morality such as preparing the actual budget realization report. The standard deviation value of 0.376 is smaller than the average value, meaning that the deviation of data on the morality variable is very small.

The minimum value for the internal control system variable is 2.36 , the maximum value is 4 and the average value is 3.29. Based on the average value, this reflects the tendency of respondents to agree on statements regarding the internal control system, working in accordance with the rules, village financial transactions that are entered and processed further after obtaining authorization, and the report is announced to the community via billboards or village websites. The standard deviation value of 0.388 is smaller than the average value, meaning that the deviation of data on the internal control system variable is very small.

The minimum value of the fraud prevention variable in village financial management is 2 and the maximum value is 4 , which means the highest value is 4. The average value of the fraud prevention variable in village financial management is 3.12. This average value reflects the tendency of respondents to agree with statements regarding fraud prevention in financial management. The standard deviation value of 0.364 is smaller than the average value, meaning that 
the deviation of data on the fraud prevention variable in village financial management is very small.

The classical assumption test is carried out as a prerequisite for the use of multiple linear regression models which require that the regression model can be used as an unbiased estimation tool if it meets the BLUE (best linear unbiased estimator) requirements.

The results of the normality test show that all variable data contribute normally. It can be seen that the Asymp. Sig. (2-tailed) has a significance of more than 0.05 , namely 0.522 . The results of multi collinearity testing were seen by the whistleblowing system variable, human resource competence, morality and internal control systems which observed VIF value $<10$ and Tolerance value $>$ 0.10 indicating that multi collinearity did not occur in the regression model. Heteroscedasticity testing shows that the significance value of each independent variable in the regression model is greater than 0.05 . This shows that the regression model does not contain heteroscedasticity, so it is feasible to predict fraud prevention.

Tabel 2. Multiple Linear Regression Test Results

\begin{tabular}{|c|c|c|c|c|c|}
\hline \multirow[t]{2}{*}{ Model } & \multicolumn{2}{|c|}{$\begin{array}{l}\text { Unstandardized } \\
\text { Coefficients }\end{array}$} & \multirow{2}{*}{$\begin{array}{c}\begin{array}{c}\text { Standardized } \\
\text { Coefficients }\end{array} \\
\text { Beta }\end{array}$} & \multirow[t]{2}{*}{$\mathrm{t}$} & \multirow[t]{2}{*}{ Sig. } \\
\hline & B & $\begin{array}{l}\text { Std. } \\
\text { Error }\end{array}$ & & & \\
\hline (Constant) & 2.376 & 2.442 & & 0.973 & 0.333 \\
\hline Whistleblowing System $\left(\mathrm{X}_{1}\right)$ & 0.060 & 0.61 & 0.101 & 0.973 & 0.333 \\
\hline $\begin{array}{ll}\text { Human } & \text { Resource } \\
\text { Competence }\left(\mathrm{X}_{2}\right) & \end{array}$ & 0.154 & 0.062 & 0.211 & 2.476 & 0.015 \\
\hline Morality $\left(X_{3}\right)$ & 0.265 & 0.117 & 0.117 & 2.262 & 0.026 \\
\hline Internal Control System $\left(\mathrm{X}_{4}\right)$ & 0.220 & 0.065 & 0.367 & 3.357 & 0.001 \\
\hline $\mathrm{R}^{2}$ & 0.442 & & & & \\
\hline Adjusted $\mathrm{R}^{2}$ & 0.417 & & & & \\
\hline F hitung & 18.187 & & & & \\
\hline Signifikansi & 0.000 & & & & \\
\hline
\end{tabular}

Source: Processed Data, 2020

Based on Table 2, the multiple linear regression equation can be prepared as follows.

$$
Y=2,376+0,060 X_{1}+0,154 X_{2}+0,265 X_{3}+0,220 X_{4+}
$$

The regression equation (1) shows that the constant value (a) is 2.376 which means that the whistleblowing system (X1), human resource competence $(\mathrm{X} 2)$, morality $(\mathrm{X} 3)$, and the internal control system $(\mathrm{X} 4)$ are constant at 0.333 , then the prevention of fraud in village financial management will increase by a constant amounting to 2.376. The whistleblowing system variable (X1) has a positive beta coefficient of 0.060 , which means that the whistleblowing system variable has a positive but insignificant effect on fraud prevention in village financial management. The human resource competency variable $(X 2)$ has a positive beta coefficient of 0.154 which means that the human resource competency variable has a positive influence on fraud prevention in village financial management. The morality variable (X3) has a positive beta coefficient of 0.265 which means that the morality variable has a positive effect on fraud prevention in village financial management. The internal control system variable 
(X4) has a positive beta coefficient of 0.220 , which means that the internal control system variable has a positive effect on fraud prevention in village financial management.

The results of the regression analysis show that the Adjusted R Square value in Table 5 is 0.417 . This means that the contribution of the influence of the independent variables, namely the whistleblowing system, human resource competence, morality and the internal control system together on fraud prevention in village financial management is 0.417 or 41.7 percent while 0.583 or 58.3 percent is explained. by other variables.

The $\mathrm{F}$ test or model feasibility test is used to see whether all the independent (independent) variables have a simultaneous influence on the dependent variable (dependent) with a significance level of $a=0.05$. If the level of significance $\mathrm{F} \leq \mathrm{\alpha}=0.05$, this model is said to be feasible. Conversely, if the level of significance $\mathrm{F}>\mathrm{a}=0.05$, the regression equation model can be said to be unfit for testing. Based on the results of the F test research in Table 5, it can be seen that the significance value is $0.000 \leq 0.05$. This shows that all the independent variables simultaneously influence the dependent variable and this regression model is suitable for use in its capacity as a predictive function.

Based on Table 2. it can be seen that the significance value of variable $X_{1}$ is $0.333 \geq 0.05$, so $\mathrm{H}_{0}$ is accepted and $\mathrm{H} 1$ is rejected. This means that the whistleblowing system has no effect on fraud prevention in village financial management. While variable $\mathrm{X}_{2}$ is $0.015 \leq 0.05$, then $\mathrm{H}_{0}$ is rejected and $\mathrm{H}_{1}$ is accepted, variable $X_{3}$ is $0.026 \leq 0.05$, then $H_{0}$ is rejected and $H_{1}$ is accepted, variable $\mathrm{X}_{4}$ is $0.001 \leq 0.05$, then $\mathrm{H}_{0}$ is rejected and $\mathrm{H} 1$ is accepted. This means that human resource competence, morality, and internal control systems have a positive effect on fraud prevention in village financial management.

The first hypothesis $\left(\mathrm{H}_{1}\right)$ is that the whistleblowing system has a positive effect on fraud prevention in village financial management. The results of hypothesis testing indicate that the whistleblowing system is not affected by fraud prevention in village financial management. It can be assumed that there is little or no possibility of fraud in village financial management in Denpasar City. Or the possibility exists that there is not yet an adequate violation reporting system for the protection of reporters in village financial management related to acts of fraud or corruption. Therefore, village officials and the community who know there are indications of fraud do not dare to report, so the reporter will need to feel safe. Likewise, if there are indications that the authorities or the community have found fraud, the officials or the community do not want to report it because they are concerned so they do not bother dealing with the law. Because whistleblowers should provide clear evidence, information or indication of the occurrence of the reported violations, so that they can be traced or followed up. This obligation must be given by the reporter in the event that the reporter is not suspected of being in good faith and is not a personal complaint based on bad will/slander.

An effective whistleblowing system requires proper structure and processes, because whistleblowers need a sense of security and safety guarantees to participate in preventing fraud and corruption. A sense of security and a guarantee of safety for both life and property for him and his family (KNKG, 
2008). Through this system, it is hoped that it can increase the level of participation of officials and the public in reporting violations.

The results of this study are in line with research conducted by Wahyuni \& Nova (2019) who found that the whistleblowing system is not the only way that can be used to prevent fraud, there are also other factors that influence it. However, the results of this study are not in line with the results of research conducted by Latifah (2011); Wardana et al. (2017) which states that the whistleblowing system has a significant effect on fraud prevention. This research is supported by research conducted by Widiyarta et al. (2017) which states that whistleblowing has a positive and significant effect on fraud prevention in the management of village funds.

The second hypothesis $\left(\mathrm{H}_{2}\right)$ states that human resource competence has a positive effect on fraud prevention in village financial management. The results of the hypothesis test show that human resource competence has a positive effect on fraud prevention in village financial management. The results of this study are in accordance with agency theory (Jensen \& Meckling, 1976). Agency theory explains that there is a relationship between principal and agent, where the principal appoints an agent to carry out a service and gives the agent authority to make decisions. In this case the Village government (agent) has received a mandate from the Central and Regional Government (principal) to carry out Village Government affairs, especially in managing village finances. This is supported by the theory of compliance explained by Mahayani (2017) that the theory of compliance consists of two, namely normative commitment through morality which means obeying the law because the law is considered a necessity and normative commitment through legitimacy means obeying the rules because the drafting authority of the law has the right to dictate behavior.

The Village Government in managing village finances must be based on the rules and regulations that have been set by the Government, namely Law of the Republic of Indonesia Number 6 of 2014 concerning Villages, Regulation of the Minister of Home Affairs of the Republic of Indonesia Number 113 of 2014 concerning Village Financial Management and Decree of the Mayor of Denpasar Number 188.45 / 345 / HK / 2018 concerning the Determination of the Amount of Village Fund Allocation to Villages in Denpasar City.

Competence of human resources in village financial management is supported by knowledge, skills and behavior. Competent human resources understand the main tasks, understand village financial planning and budgeting and are able to compile village financial reports, comply with social norms and applicable regulations and reject all forms of bribery.

This explanation is supported by the results of research in the field which show that most of the Village Governments in 27 Dinas Villages in Denpasar City have the latest S1 education, which means that the competence of human resources in village financial management in villages in Denpasar City has competencies that good. So that in village financial management, fraud can be minimized and avoided so that the purpose of providing village fund allocations intended for community needs can be appropriate.

The results of this study are consistent with previous studies. Huslina et al. (2015) states that apparatus competence has a positive effect on the 
effectiveness of the fraud prevention system. This research is supported by research conducted by Widiyarta et al. (2017) which states that the competence of village government has a positive and significant effect on fraud prevention in village financial management. Likewise, the research results of Wonar et al. (2018) that the competence of village officials has a positive and significant effect on fraud prevention.

Third hypothesis $\left(\mathrm{H}_{3}\right)$ states that morality has a positive effect on fraud prevention in village financial management. The results of hypothesis testing show that morality has a positive effect on fraud prevention in village financial management. The results of this study are supported by the theory of moral development described by Kohlberg \& Hersh (1977), namely at the preconventional and post-conventional stages. Where at the lowest stage (preconventional) it is explained that individuals base their actions because they are afraid of existing laws or regulations and at the highest (post-conventional) stage individuals base their actions with regard to the interests of others and based on their actions on universal laws.

With this concept, the Village Government in managing village finances must obey in carrying out its duties and obligations in accordance with the mandate given by the Government through established regulations and laws so that the management of village finances can be accounted for, not only to the Central and Regional Government but also the community. The use of village fund allocations by the Village Government must be in accordance with the needs of the village and the community, especially in village development, guidance and community empowerment. Good morality is needed because good morality reflects good behavior. Therefore, in the management of village finances, good morality from the Village Government is needed so that the use of village fund allocations can be used in accordance with the mandate given by the Central and Regional Government and also for the benefit of many people, namely the village community. Therefore, morality is needed to prevent fraud in village financial management.

The results of this study are supported by research conducted by Wardana et al. (2017) which states that partially apparatus morality has an effect on fraud prevention. Atmadja \& Saputra (2017) found that good morality can prevent fraud in the management of village funds. This is in line with research conducted by Rahimah et al. (2018) which proves that morality affects the prevention of fraud in the allocation of village funds.

The fourth hypothesis $\left(\mathrm{H}_{4}\right)$ states that the internal control system affects fraud prevention in village financial management. The results of hypothesis testing indicate that the internal control system has a positive effect on fraud prevention in village financial management. This is supported by the concept of an internal control system in the Government Regulation of the Republic of Indonesia Number 60 of 2008 concerning the Government Internal Control System which explains that the purpose of an internal control system is to provide adequate confidence in the achievement of organizational goals through effective and efficient activities, reliability of financial statements and obedience to laws and regulations. 
With a strong internal control system, it can reduce risks or mistakes or errors in compiling village financial reports so as to create quality reports that are in accordance with predetermined regulations and can be accounted for. The results of this study indicate that the internal control system in the Village Government in 27 Dinas Villages in Denpasar City in managing village finances is strong. Where a strong control system supported by a control environment, risk assessment, control activities, information and communication as well as internal control monitoring. So that fraud in village financial management can be minimized and prevented.

The results of this study are consistent with previous studies. Soleman (2013) states that internal control has a positive effect on fraud prevention. This research is in line with research conducted by Atmadja \& Saputra (2017) which proves that the internal control system affects fraud prevention in village financial management.

\section{CONCLUSION}

The whistleblowing system has no effect on the prevention of fraud in village financial management, it is assumed that there is yet to be an adequate violation reporting system for the protection of reporters related to a sense of security and safety assurance.

Human resource competence has a positive effect on fraud prevention in village financial management. This means that the competence of human resources in knowledge, skills and behavior in compliance with social norms and applicable regulations can prevent fraud in village financial management.

Morality has a positive effect on fraud prevention in village financial management. This may imply that good morality in village financial management, supported by good performance, not prioritizing personal interests and the use of village finances that considers the principles of community welfare can prevent fraud.

The internal control system has a positive effect on fraud prevention in village financial management. The more adequate internal control system in the control environment, risk assessment, control activities, information and communication as well as internal control monitoring can prevent fraud in village financial management.

Practically, if the village apparatus who manages village finances has high competence, good morality and an adequate internal control system, it can give confidence to the Central and Regional Government and the community that the use of village fund allocations given is in accordance with the interests and needs of the community and village development.

This research was only conducted in Denpasar City during the study period, so the results cannot be generalized to all cities or districts in Indonesia. So that researchers who are interested in this topic can expand the location and research variables.

Based on the research results and conclusions, several suggestions can be made, namely that village officials continue to pay attention to and improve the competence of human resources, maintain morality or good work ethics and pay attention to an adequate internal control system. It is hoped that village officials 
will ensure more security, confidentiality and safety assurance if whistleblowers are willing to provide information on fraud in village financial management.

\section{REFERENCES}

Agusyani, K. S., Sujana, E., \& Wahyuni, M. A. (2016). Pengaruh Whistleblowing System Dan Kompetensi Fraud Pada Pengelolaan Keuangan Penerimaan Pendapatan Asli Daerah (Studi Pada Dinas Pendapatan Daerah Kabupaten Buleleng). E-Journals1 Ak Univ Pendidikan Ganesha, 6(3). https://ejournal.undiksha.ac.id/index.php/S1ak/article/view/8801

Aini, N., Prayudi, M. A., \& Diatmika, P. G. (2017). Pengaruh Perspektif Fraud Diamond Terhadap Kecenderungan Terjadinya Kecurangan (Fraud) Dalam Pengelolaan Keuangan Desa (Studi Empiris Pada Desa Di Kabupaten Lombok Timur). E-Jurnal Akuntansi Universitas Pendidikan Ganesha, 8(2). https:// ejournal.undiksha.ac.id/index.php/S1ak/article/download/14583 /8903

Ariyanto, D., Firdaus, G. M., Sari, M. M. R., Dewi, A. A., \& Made Gilang Jhuniantara, I. (2020). How self control and situational pressure influence the tendency to receive gratification: An experimental study. International Journal of Criminology and Sociology, 9, 400-414. https:// doi.org/10.6000/1929-4409.2020.09.39

Atmadja, A. T., \& Saputra, A. K. (2017). Pencegahan Fraud dalam Pengelolaan Keuangan Desa. Jurnal Ilmiah Akuntansi Dan Bisnis, 12(1), 7-16. https:// doi.org/10.24843/jiab.2017.v12.i01.p02

Dennyningrat, I. G. A. G., \& Suputra, I. D. G. D. (2018). Pengaruh Sistem Pengendalian Intern Pemerintah dan Moralitas Individu pada Kesalahan Akuntansi. E-Jurnal Akuntansi, 22(2), 1170-1196. https:// doi.org/10.24843/eja.2018.v22.i02.p13

Dewi, P. F. K., Yuniarta, G. A., \& Wahyuni, M. A. (2017). Pengaruh Moralitas, Integritas, Komitmen Organisasi, Dan Pengendalian Internal Kas Terhadap Pencegahan Kecurangan (Fraud) Dalam Pelaksanaan Program Subsidi Beras Bagi Masyarakat Berpendapatan Rendah (Studi Pada Desa Di Kabupaten Buleleng). E-Journal S1 Ak Universitas Pendidikan Ganesha, 8(2). https://ejournal.undiksha.ac.id/index.php/S1ak/article/view/13310

Ferina, I., Burhanuddin, B., \& Lubis, H. (2016). Tinjauan Kesiapan Pemerintah Desa dalam Implementasi Peraturan Menteri Dalam Negeri Nomor 113 Tahun 2014 Tentang Pengelolaan Keuangan Desa (Studi Kasus Pada Pemerintah Desa di Kabupaten Ogan Ilir). Jurnal Manajemen Dan Bisnis Sriwijaya, 14(3), 321-336. https:// doi.org/10.29259/jmbs.v14i3.3991

Huslina, H., Islahuddin, \& Syah, N. (2015). Pengaruh Integritas Aparatur, Kompetensi Aparatur, Dan Pemanfaatan Teknologi Informasi Terhadap Efektivitas Sistem Pencegahan Fraud. Jurnal Administrasi Akuntansi : Program Pascasarjana Unsyiah, 4(1), 55-64.

IAPI. (2013). SA Seksi 316. In Standar Profesional Akuntan Publik.

Indonesian Corruption Watch. (2018). Outlook dana desa 2018 potensi penyalahgunaan anggaran desa di tahun politik. Www.Antikorupsi.Org.

Indriani, I., Suroso, A., \& Maghfiroh, S. (2016). Penerapan Konsep Fraud Diamond Theory Dalam Mendeteksi Perilaku Fraud. Simposium Nasional 
Akuntansi XIX, Lampung.

Jensen, M. C., \& Meckling, W. H. (1976). Theory of the firm: Managerial behavior, agency costs and ownership structure. Journal of Financial Economics. https:// doi.org/10.1016/0304-405X(76)90026-X

Junia, N. (2016). Pengaruh Moralitas Aparat, Kesesuaian Kompensasi dan Ketaatan Aturan Akuntansi Terhadap Kecenderungan Kecurangan Akuntansi. JOMFekom, 4(1), 1960-1970.

KNKG. (2008). Komite Nasional Kebijakan Governance. In PCWorld.

Kohlberg, L., \& Hersh, R. H. (1977). Moral Development: A Review of the Theory. Theory Into Practice, 16(2), 53-59. https:/ / doi.org/10.1080/00405847709542675

Larasati, Y. S., Sadeli, D., \& Surtikanti, S. (2017). Analisis Faktor-Faktor Yang Berpengaruh Terhadap Pencegahan Fraud Di Dalam Proses Pengadaan Barang Dan Jasa. JIAFE (Jurnal Ilmiah Akuntansi Fakultas Ekonomi), 3(2), 4360. https://doi.org/10.34204/jiafe.v3i2.759

Latifah, I. (2011). Pengaruh Efektivitas Whistleblowing dan Pencegahan Fraud terhadap Pencegahan Fraud ( Survei pada Karyawan Otoritas Jasa Keuangan Regional 2 Jawa Barat ). Prosiding Akuntansi, 484-495.

Liyanarachchi, G., \& Newdick, C. (2009). The impact of moral reasoning and retaliation on whistle-blowing: New Zealand evidence. Journal of Business Ethics, 8(9). https:/ / doi.org/10.1007/s10551-008-9983-x

Mahayani, N. L. A. (2017). Prosocial Behavior dan Persepsi Akuntabilitas Pengelolaan Dana Desa Dalam Konteks Budaya Tri Hita Karana. Jurnal Ilmiah Akuntansi Dan Bisnis, 12(2), 129-144.

Manossoh, H. (2016). FAKTOR-FAKTOR PENYEBAB TERJADINYA FRAUD PADA PEMERINTAH DI PROVINSI SULAWESI UTARA. Jurnal Riset Ekonomi, Manajemen, Bisnis Dan Akuntansi. https:// doi.org/10.35794/emba.v4i1.11649

Novikasari, Y., Desmiyawati, D., \& Silfi, A. (2016). Pengaruh Moralitas Individu, Sistem Pengendalian Intern Pemerintah, Dan Ketaatan Aturan Akuntansi Terhadap Kecenderungan Kecurangan Akuntansi (Studi Empiris pada SKPD Kab. Kuantan Singingi). Jurnal Online Mahasiswa Fakultas Ekonomi Universitas Riau.

Putri, C. D., Yuniarta, G. A., \& Prayudi, M. A. (2017). Pengaruh Pengetahuan Peraturan, Kompetensi Sumber Daya Manusia, Monitoring dan Evaluasi Terhadap Efektivitas Sistem Pengendalian Internal Pemerintah Desa (Studi pada Desa Se-Kabupaten Karangasem). E-Journal S1 Ak Universitas Pendidikan Ganesha, 8(2).

Rahimah, L. N., Murni, Y., \& Lysandra, S. (2018). Pengaruh Penyajian Laporan Keuangan Desa, Lingkungan Pengendalian dan Moralitas Individu terhadap Pencegahan Fraud yang terjadi dalam Pengelolaan Alokasi Dana Desa. Jurnal Ilmiah Ilmu Ekonomi, 6(12), 139-154.

Setiawan, S. (2018). The Effect Of Internal Control And Individual Morality On The Tendency Of Accounting Fraud. Asia Pacific Fraud Journal, 3(1), 33-41. https:// doi.org/10.21532/apfj.001.18.03.01.04

Soleman, R. (2013). Pengaruh pengendalian internal dan good corporate governance terhadap pen cegahan fraud. Jurnal Akuntansi $\mathcal{E}$ Auditing 
Indonesia, 17(1), 57-74. https:// doi.org/10.20885/jaai.vol17.iss1.art5

Suarna, N. (2020). Tersandung Korupsi APBDes, Perbekel Pemecutan Kaja Ditahan. Bali Express. https:/ / baliexpress.jawapos.com/

Sugiarti, E., \& Yudianto, I. (2017). Analisis Faktor Kompetensi Sumber Daya Manusia, Pemanfaatan Teknologi Informasi, dan Partisipasi Penganggaran Terhadap Akuntabilitas Pengelolaan Dana Desa. Proceedings Profesionalisme Akuntan Menuju Sustainable Business Practice, 580-590.

The Committee of Sponsoring Organizations, C. (2013). Internal control integrated framework: executive summary. New York.

Wahyuni, E. S., \& Nova, T. (2019). Analisis Whistleblowing System Dan Kompetensi Aparatur Terhadap Pencegahan Fraud (Studi Empiris Pada Satuan Organisasi Perangkat Daerah Kabupaten Bengkalis). Inovbiz: Jurnal Inovasi Bisnis, 6(1), 189-194. https://doi.org/10.35314/inovbiz.v6i2.867

Wardana, I. G. A. K., Sujana, E., \& Wahyuni, M. A. (2017). Pengaruh Pengendalian Internal, Whistleblowing System Dan Moralitas Aparat Terhadap Pencegahan Fraud Pada Dinas Pekerjaan Umum Kabupaten Buleleng. E-Journal S1 Ak Universitas Pendidikan Ganesha, 8(2).

Wardani, D. K., \& Andriyani, I. (2017). Pengaruh Kualitas Sumber Daya Manusia, Pemanfaatan Teknologi Informasi, Dan Sistem Pengendalian Intern Terhadap Keandalan Pelaporan Keuangan Pemerintahan Desa Di Kabupaten Klaten. Jurnal Akuntansi, 5(2), 88-98. https:// doi.org/10.24964/ja.v5i2.270

Widiyarta, K., Herawati, N. T., \& Atmadja, A. T. (2017). Pengaruh Kompetensi Aparatur, Budaya Organisasi, Whistleblowing Dan Sistem Pengendalian Internal Terhadap Pencegahan Fraud Dalam Pengelolaan Dana Desa (Studi Empiris Pada Pemerintah Desa Di Kabupaten Buleleng). E-Journal S1 Ak Universitas Pendidikan Ganesha, 8(2).

Wijaya, D. (2018). BUM Desa Badan Usaha Milik Desa. Yogyakarta: Penerbit Gava Media.

Wonar, K., Falah, S., \& Pangayow, B. J. . (2018). Pengaruh Kompetensi Aparatur Desa, Ketaatan Pelaporan Keuangan dan Sistem Pengendalian Intern Terhadap Pencegahan Fraud Dengan Moral Sensitivity Sebagai Variabel Moderasi. Jurnal Akuntansi, Audit E Aset, 1(2), 63-89. 